\title{
BASILAR IMPRESSION ASSOCIATED WITH IMPACTED CISTERNA MAGNA, SPASTIC PARAPARESIS AND DISTRESS OF BALANCE
}

\author{
Case report
}

\author{
José Alberto Gonçalves da Silva', Maurus Marques de Almeida Holanda', \\ Maria do Desterro Leiros², Luiz Ricardo Santiago Melo', \\ Antônio Fernandes de Araújo', Everardo Bandeira de Almeida ${ }^{3}$
}

\begin{abstract}
We report on a 48 years-old man with basilar impression without syringohydromyelia, in which the cisterna magna was impacted by the cerebellar tonsils. Six months after posterior fossa decompression there was the disappearance of nuchal rigidity, vertigo, spastic paraparesis and improvement of balance. Nevertheless hyperreflexia and diminished pallesthesia of the lower limbs persisted.
\end{abstract}

KEY WORDS: basilar impression, Chiari malformation, syringomyelia, posterior fossa decompression, tight cisterna magna.

\begin{abstract}
Impressão basilar associada com cisterna magna impactada, paraparesia espástica e distúrbios do equilíbrio: relato de caso

RESUMO - O presente relato descreve um homem de 48 anos com impressão basilar, sem siringo-hidromielia, no qual a cisterna magna se achava impactada pelas tonsilas cere bela res. O quadro clínico era caracterizado, especialmente, por paraparesia espástica. Seis meses após a descompressão da fossa posterior houve regressão da rigidez de nuca, vertigem, paraparesia espástica inicialmente observadas e melhora do equilíbrio. A hiperreflexia e a hipopalestesia persistiram nos membros inferiores.
\end{abstract}

PALAVRAS-CHAVE: impressão basilar, malformação de Chiari, siringomielia, descompressão da fossa posterior, cisterna magna impactada.

Hans Chiari ${ }^{1,2}(1891,1895)$ described four types of cerebellar anomalies. Type I was characterized by downward displacement of the cerebellar tonsils and the medial portions of the inferior cerebellar lobes, which accompanied the medulla into the cervical spinal canal. The type II showed downward displacement of portions of the cerebellum (1891), and portions of the inferior vermis (1895), pons, medulla oblonga and, at least, a part of lengthened fourth ventricle, which reached the disc C 4 - C 5, into the enlarged cervical spinal canal. In type III, the hydrocephalic cerebellum, pons and medulla were inside a cervical meningocele (hydroencephaloceles cerebellaris cervicalis), through a spina bifida of the first three cervical vertebrae. In type IV, there was hypoplasia of the cerebellum without herniation of cere- bellar structures into the spinal canal. Iskandar et al. ${ }^{3}$ (1998) related five cases of siringohydromyelia (SM), in which the cisterna magna was filled by the cerebellar tonsils. In all five cases there was clinical improvement after decompression of the posterior fossa and a marked reduction in the size of syrinx. These authours admitted that this dramatic response to decompression indicates that this entity has a Chiarilike pathophysiology. On the other hand, Kyoshima et al. ${ }^{4}$ related four similar cases with improvement in symptoms and a reduction in syrinx size in three patients, and a reduction in ventricle size in two. These authors named the impacted cisterna magna by the cerebellar tonsils "tight cisterna magna", and called the description according to Iskandar et al. ${ }^{3}$, "Chiari "0" malformation".

Neurosurgical Unit Hospital Santa Isabel, João Pessoa PB, Brazil: ${ }^{1}$ Neurosurgeon; ${ }^{2}$ Neurologist; ${ }^{3}$ Neuroanesthesist.

Received 8 December 2005, received in final form 7 March 2006. Accepted 25 April 2006.

Dr. José Alberto Gonçalves da Silva - Avenida Minas Gerais 1150 - 58030-092 João Pessoa PB - Brasil. 
The present case offers some resemblances with the pathophysiology, described by Iskandar et al. ${ }^{3}$. This paper is based on the rareness of the clinical picture, characterized by brevis collis, nuchal rigidity, ve rtigo, spastic paraparesis, diminished unstead gait and diminished pallesthesia of the lower limbs.

\section{CASE}

A 48-year-old man presented, with a history of progressive loss of muscular strength of the lower limbs, daily vertigo and distress of balance. The neurological exam presented brevis collis, nuchal rigidity, distress of balance, spastic paraparesis, marked hyperactive patell ar and Achilles reflexes and diminished pallesthesia of the lower limbs. The $X$ rays of the skull showed basilar impression (BI) and a normal anatomic configuration of the foramen magnum. The magnetic resonance imaging (MRI) depicted the presence of $\mathrm{BI}$, absence of the cisterna magna and the brain stem seemed not to be compressed by the odontoid process (Fig 1).

The indication for the follow ing surgical treatm ent is concerned to the impacted cisterna magna. During the osteodural-neural decompression of the posterior fossa, carried out with the patient in sitting position ${ }^{5,6}$, we observed the following abnormalities: pulseless dura-mater, diffuse arachnoiditis, compression of the fourth ventricle and the foramen of Magendie by the cerebellar tonsils which filled the cisterna magna and migrated partially downwards into the cervical spinal canal (Fig 2). The cerebellar tonsils were yellowish, lightly atrophic and presented some arachnoid adherences to neighboring structures. We performed intrapial aspiration of the cerebellar tonsils and the residual pial sac was sutured upwards to the duramater in cranial lateral position (Fig 3). Six months after posterior fossa decompression, we observed disappearance of nuchal rigidity, vertigo, spastic paraparesis and amelio-

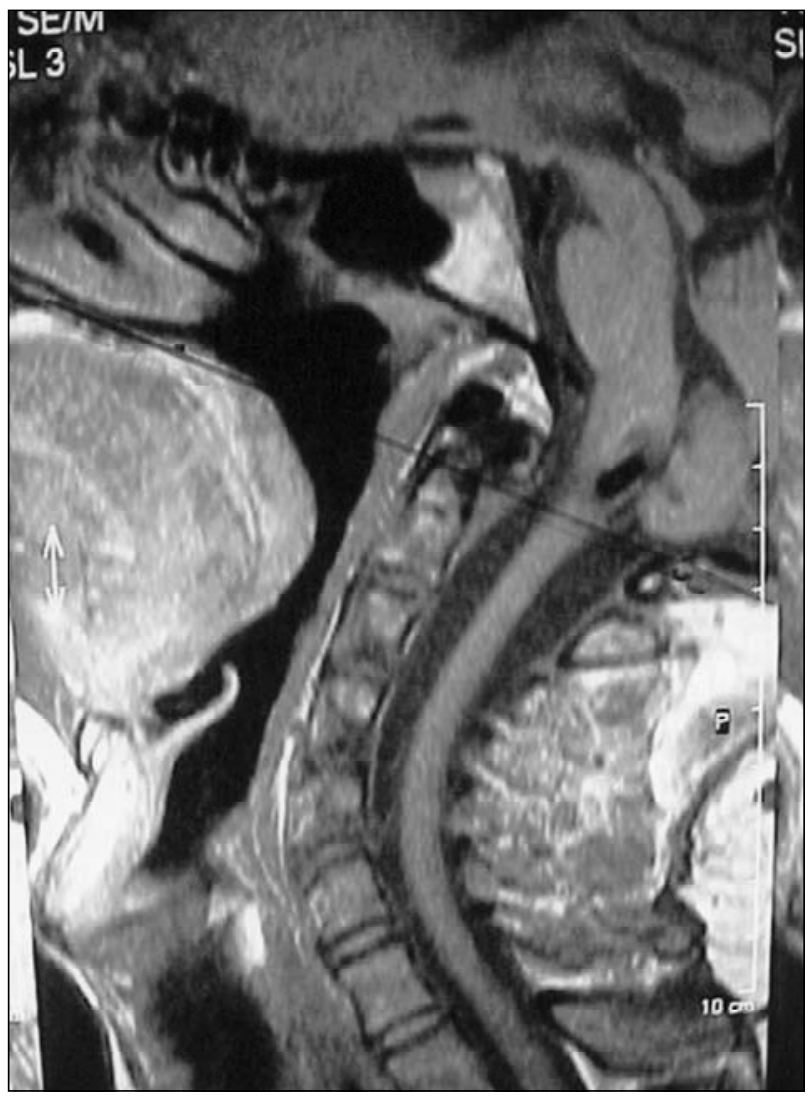

Fig 1. Impacted cisterna magna and BI.

ration of the balance distress, while the signs of pyramidal liberation and the diminished pallesthesia of the lower limbs remaind unchanged. The postoperative MRI revealed the created cisterna magna (Fig 4).

This study was approved by the apropriate Bioethics Research Committee.

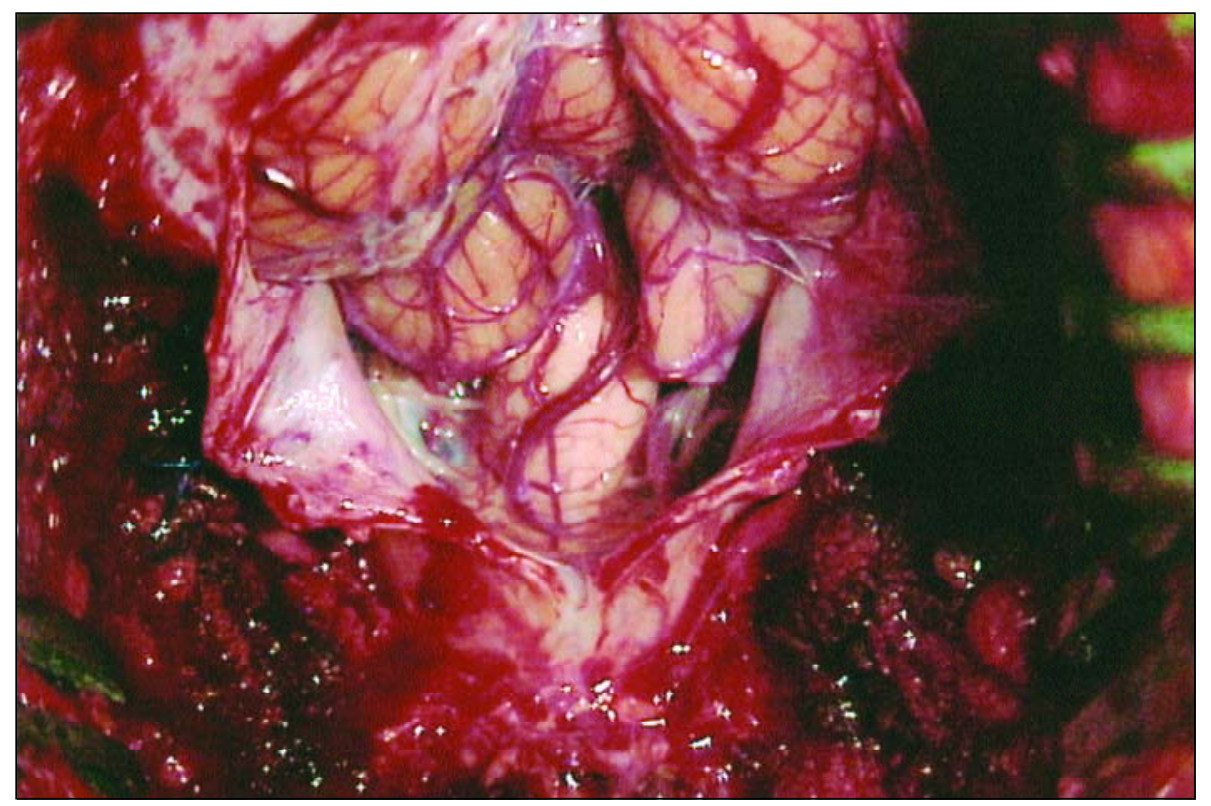

Fig 2. Partially downwards migra tion of the cerebellar tonsils dur ing operation in sitting position. 
Fig 3. Tonsilectomy, large opening of the fourth ventricle and fixation of the residual pial sac to the lat eral dura-mater in cranial lateral position.

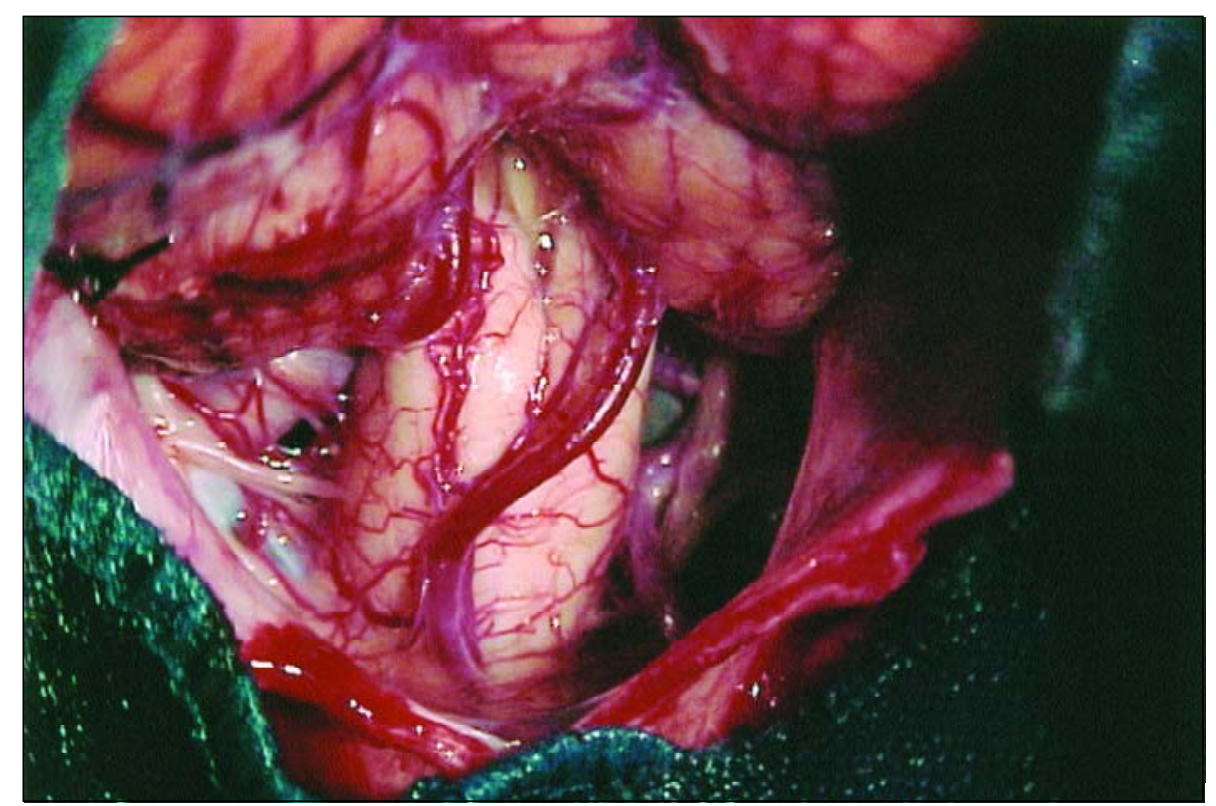

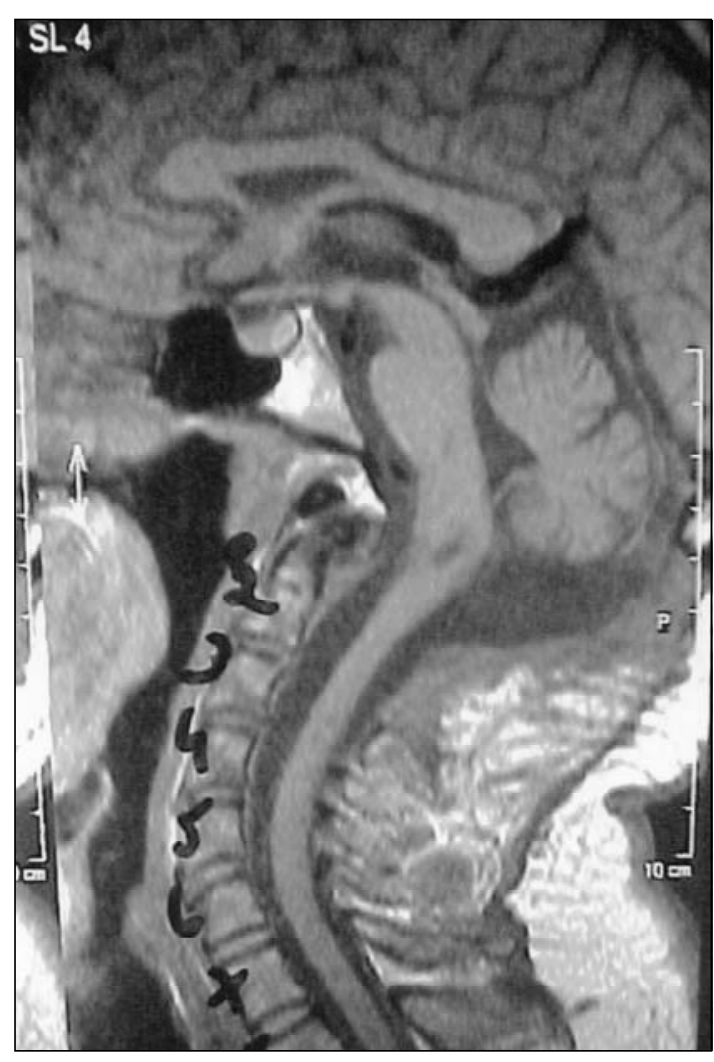

Fig 4. Postoperative MRI showing the new created cis terna magna.

\section{DISCUSSION}

In the present re p ort we describe the association of $\mathrm{BI}$ and impacted cisterna magna. The $\mathrm{X}$ rays showed the presence of $\mathrm{BI}$ and a normal anatomic configuration of the foramen magnum, whose posterior border do not penetrate into the posterior fossa. The preoperative MRI depicted an impacted cisterna magna, without herniation into the cervical spinal canal, without SM. The brainstem seemed not to be compressed by the odontoid process. However, during the operation performed with the patient in sitting position, we noticed small herniation of the cerebellar tonsils below the foramen magnum. This observation was also described by Iskandar et al. ${ }^{3}$ and Gonçalves da Silva et al. ${ }^{7}$, in which the cerebellar tonsils we re located, during the operation, below the foramen magnum. Possibly the cerebellar tonsils have a tendency to migrate downwards on the ortostatic position. In the future, with the introduction of MRI carried out with the patient in upright position, we p robably shall be able to detect a diff e rence of the ce rebellar tonsils topography in both the dorsal and the ortostatic position.

The impactation of the cerebellar tonsils in the cisterm magna, without herniation into the cervical spinal canal, also causes disturbances of the cerebral spinal fluid (CSF) flow to the foramen magnum, according to Iskandar et al. ${ }^{3}$, and can provoke neurological symptomatology by compression of the brainstem and the cerebellar pathways.

Spastic tetraparesis and paraparesis are frequently described in patients with $\mathrm{BI}$ and/or Chiari malformations $(\mathrm{CM})$, in which distress of balance is observed in cases of $\mathrm{CM}^{8-16}$.

The pathophysiology of this case could have been developed either by $\mathrm{BI}$ or the impacted cisterna magna. However, the BI does not show signs of com- 
p ression of the brainstem and the posterior border of the foramen magnum does not penetrate into the posterior fossa. Possibly the brevis collis and the nuchal rigidity were caused by the $\mathrm{BI}$, while the impacted cisterna magna developed other signs like vert igo, distress of balance, spastic paraparesis and diminished pallesthesia of the lower limbs.

Mo restudies should be carried out re ga rding impacted cisterna magna, isolated or associated with other pathologies, with the purpose of defining correctly this diagnosis and the subsequent posterior fossa decompression. The study of CSF flow is a very important method for the diagnosis of the tight ciste rna magna, but unfortunately this exam is not at our dispose.

Acknowledgements - This paper is dedicated with thanks to Prof. Dr. Med. H. c. Hans-Jürgen Reulen.

\section{REFERENCES}

1. Chiari H. Über Veränderungen dês Kleinhirns inforlge von Hydrocephalie des Grosshirns. Dtsch med Wschr 1891;17:1172-1175.

2. Chiari H. Über Veränderungen des Kleinhirns, des Pons und der Medulla Oblongata in Folge von congenitaler Hydrocephalie dês Grosshirns. Dtsch Akd Wiss 1895;63:71-85.

3. Iskandar BJ, Hedlund GL, Grabb PA, Oakes WJ. The resolution of syringohydromyelia without hindbrain herniation after posterior fossa decompression. J Neurosurg 1998;89:212-216
4. Kyoshima K, Kuroyanagi T, Oya F, Kamijo Y, El-Noamany H, Kobayasi S. Syringomyelia without hindbrain herniation: tight cisterna magna: report of four cases and review of the literature. J Neurosurg (Spine 2) 2002:96:239-249.

5. Gonçalves da Silva JA. Resultados do tratamento cirúrgico da impressão basilar e malformação de Arnold-Chiari: estudo de 72 casos. Tese. João Pessoa, 1977.

6. Gonçalves da Silva JA. Malformações occipitocervicais. In Melo Souza SE (ed). Tratamento das doenças neurológicas. Rio de Janeiro, Guanabara Koogan, 2000:772-774.

7. Gonçalves da Silva JA, Holanda MMA, Pereira CB, Leiros MD, Araújo AF, Bandeira E. Retropulsion and vertigo in the Chiari malformation. Arq Neuropsiquiatr 2005;63:870-873.

8. Arruda JAM. Tratamento da siringomielia associada à malformação de Chiari: análise de 30 casos. Tese. São Paulo, 1996.

9. Arruda JAM. Tratamento da siringomielia associada à malformação de Chiari: análise de 60 casos. Tese. São Paulo, 2001.

10. Caetano de Barros M. Contribuição ao estudo da impressão basilar associada à malformação de Arnold-Chiari. Tese. Recife, 1959.

11. Canelas HM, Zaclis J, Tenuto RA. Contribuição ao estudo das malformações occipitocervicais, particularmente da impressão basilar. A rq Neuropsiquiatr 1952;10:407-476

12. Canelas HM, Zaclis J, Tenuto RA, Cruz OR. Malformações occipitocervicais: a propósito de vinte novos casos. A rq Neuropsiquiatr 1956;14: $1-27$.

13. Carnei roGSFilho. Tratamento-circunferendalda invaginação basilar. Tese. Recife, 2001.

14. Gonçalves da Silva JA, Holanda MMA. Basilar impression, Chiari malformation and syringomyelia: a ret rospective study of 53 surgically treated patients. Arq Neuropsiquiatr 2003;61:368-375.

15. Gonçalves da Silva JA. Malformações occipitocervicais: impressão basilar, malformação de Chiari, siringomielia, platibasia. Recife: Editora Universitária / UFPE, 2003.

16. Taricco MA. Tratamento cirúrgico da siringomielia associada à malformação de Chiari tipo I. Tese. São Paulo, 1994. 